\title{
Resituating Africa's Urban Informal Food Sector
}

\section{Jonathan Crush ${ }^{1,2} \cdot$ Graeme Young $^{1}$}

\begin{abstract}
The complex dynamics of the informal food sector in urban Africa are poorly understood. Urban informal food systems are beginning to receive attention from scholars and policymakers, but the notable absence of detailed empirical information and necessary theoretical engagement with their emergence, structure, and operation has thus far limited efforts to understand the central role that they play in urban development processes. This Special Issue brings together a diverse collection of case studies from seven countries across the Global South - China, Jamaica, Mozambique, Namibia, Nigeria, South Africa, and Uganda - to explore these dynamics by placing Africa's urban informal food sector in comparative international context. This introduction provides an overview of how this Special Issue contributes to debates about the origins of informal food economies in cities in the Global South, the potential of the informal food sector to contribute to inclusive urban development, the relationship between informal food vendors and the state, and interactions between formal and informal food systems, all of which have important implications for theorizing urban governance and development in Africa and beyond.
\end{abstract}

Keywords Urbanization · Global south · Informal sector · Food retail · Food security · Food · System governance

This Special Issue presents a set of evidence-based papers that address the complex dynamics of informal food economies in African cities and places them in comparative perspective. The papers were initially presented at a conference on Urbanization, Food Systems and Sustainability in the Global South in Waterloo, Canada, in July 2018 cohosted by the Hungry Cities Partnership, the Sustainable Development Solutions Network, and the Queen Elizabeth Advanced Scholars Program. By including case studies of six different African cities in five countries (Mozambique, Namibia, Nigeria, South Africa, and Uganda), the Special Issue highlights the complexities of food

Jonathan Crush

jcrush@balsillieschool.ca

1 Balsillie School of International Affairs, Waterloo, Ontario N2L6C2, Canada

2 University of Western Cape, Bellville, South Africa 
system informality and the multiplicity of ways in which they can be understood. In addition, case studies from the two very different contexts of Jamaica and China are included to demonstrate the value of broader comparisons in thinking about informal food economies in African cities.

Informal economic activity clearly plays an increasingly central role in urban food systems in Africa under conditions of rapid urbanization (Battersby and Watson 2019; Crush and Battersby 2016; Frayne et al. 2018; Skinner 2019; Young and Crush 2019). From production and distribution to point of sale and waste management, food-related activities that are outside formal legal and regulatory systems permeate all levels of urban food value chains and post-consumption processes. Understanding how these informal food economies operate is not only crucial for urban food security but also demands an engagement with broader questions of urban development, poverty, unemployment, patterns of inclusion and exclusion, and sustainable and inclusive growth. Despite their importance, informal food economies are conspicuously absent from current food policy debates (Skinner and Haysom 2016). This is a significant oversight that both reflects and feeds into forms of governance that are often ad hoc, incoherent, and ultimately harmful to the livelihoods of the urban poor.

Scholars have made tentative steps to provide a corrective for the widespread failure to systematically engage with informal food economies, but major theoretical questions remain unanswered and detailed empirical information on their nature and operation is still limited. A better understanding of the informal food sector in Africa and other cities in the Global South first needs to address the pervasiveness of informality more generally. The question of why informal economies exist has attracted attention since at least the 1970s. Three perspectives have come to dominate the literature: (a) dualist views that frame informality as a feature of underdevelopment and the result of exclusion from the formal economy (Hart 1973); (b) structuralist views that present informality as a form of exploitation that is a key feature of capitalist development (Portes et al. 1989); and (c) neoliberal accounts that hold informality to be a form of grassroots entrepreneurship in which poorly designed laws and regulations incentivize widespread disengagement from the state (de Soto 1989). Each interpretation has different policy implications. If informality is the result of the labour market exclusion that characterizes underdevelopment, for example, then states should prioritize formal job creation and development processes. If, on the other hand, it stems from systems of exploitation that are inherent in capitalist development, then alternative forms of popular empowerment are necessary. And if it is caused by burdensome requirements for participation in the formal economy, then the state must focus on reforming its legal and regulatory systems to incentivize compliance and participation.

An alternative view of informal economic activity in African cities is that it can only be properly understood through a historically rooted political economy approach that emphasizes the role of the state in its production and perpetuation. The idea that the informal economy exists separate from the state and outside of the scope of state power is relatively common, but fundamentally flawed, as it ignores the historical, institutional, political, and economic processes that tie the state to the informal sphere. It is essential to understand how these political economies and historical trajectories impact informal economic activity and to move away from broader ahistorical, apolitical, and decontextualized theoretical interpretations that fail to grasp that informal economies are highly complex and deeply embedded in the specific environments in which they exist. 
Engaging with the relationship between informality and the state naturally leads to a consideration of the forces that shape the governance of informal economic activity. Studies in other contexts convincingly contend that the political, economic, and social circumstances in which vending takes place shape its treatment by the state (Holland 2017; Mackie et al. 2014; Roever and Skinner, 2016). Using Kampala as a case study, Graeme Young (in this issue) argues that there are at least six ways in which the state has shaped, and continues to shape, informality in the African city: the legacies of colonial planning; a post-colonial history of poor governance and instability; extensive economic liberalization; the unequal geographies of development; a poorly designed system of taxation; and the self-interest of state officials who benefit, in various ways, from the existence of informal economies (see Young 2017, 2018). However, the precise ways in which central and local states produce and shape the growth of informality vary between countries, subnational units, and cities. This means that these factors are not necessarily all present, or function in exactly the same way, where the political economy of the state and the historical trajectory of state/society relations differ, both within Africa and elsewhere.

Much of the existing literature on contemporary informal vending in African cities frames the historical and contemporary relationship between vendors and the state in oppositional terms, as characterized by neglect, mistrust, hostility, and/or various forms of control and contestation. The use of state power to eradicate informal food vending by forcibly removing traders from city streets and/or relocating them to designated trading areas, often fuelled by management and development ambitions that seek to protect formal businesses and impose modernist visions of urban aesthetics and functionality, is well-documented across the continent (Crush et al. 2017a; Finn 2018; Kamete 2013, 2017; Riley 2014; Resnick forthcoming; Tonda and Kepe 2016; Young 2017). So, too, are the strategies employed by informal vendors to contest these efforts (Bénit-Gbaffou, 2016, Moyo 2018; Musoni 2010; Steel et al. 2014, Young 2018). These conflicts can have significant livelihood impacts on informal food vendors and, given the extent to which the informal economy facilitates access to food, undermine urban food security.

Recent studies have suggested that a more nuanced approach may be necessary to capture the full spectrum of interactions between states and informal food vendors (Dragsted-Mutengwa 2018, Kazembe et al. 2019). One suggestion is that the effectiveness of state repression is compromised by forms of "relational governance" in which police and municipal officials extort payment in exchange for turning a blind eye to informal vending (Dragsted-Mutengwa 2018). Three of the papers in this Special Issue highlight other ways in which the repressive instincts of states towards informal food vendors are undermined. Danielle Resnick and colleagues (in this issue) focus on two secondary cities in Nigeria, Calabar and Minna, and show that vendors in these secondary urban centers experience much less harassment by state officials than in larger Nigerian cities, such as Lagos, where draconian responses to informality are commonplace. This environment of "benign neglect" is a function of both "low capacity and a high degree of opacity in governance of informal vending." In both cities, traders report very little engagement with state-level authorities charged with overseeing the sector. Instead of harsh repression, informal food vendors in these secondary urban centres consequently operate in something of an enabling environment for their activities. Further studies of secondary cities in other countries are necessary to 
ascertain whether this is a peculiar feature of Nigeria or a more general feature of secondary urbanization in Africa.

Robert Kinlocke and Elizabeth Thomas Hope (in this issue) argue that in Kingston, Jamaica, informal vendors operate in a policy environment heavily affected by a recent history of neoliberal state policies, including the elimination of barriers to food imports, the decline of formal employment, and the reduction of agricultural subsidies. The associated contraction of the state has not prevented the regular harassment of street food vendors. However, the informal food sector is characterized by a strong ethic of reliance on social networks to generate the capital needed for start-up and to protect vendors from both crime and state depredation. Given the extent to which neoliberal policies have also reshaped economies and transformed state-society relations in Africa (Poku and Whitman 2017), this analysis offers a particularly useful point of departure for analysis of the informal food economy in African cities (Morange 2015). Most notably, it offers a potential corrective to suggestions that economic liberalization and its political and institutional effects have limited the ability of informal economic activity embedded in social networks to contribute to inclusive development (Meagher 2010).

In Nanjing, China, an altogether different scenario has emerged with extreme levels of state control of all facets of the urban food system. Here we see a carefully planned and executed policy of what Kamete (2018), in the African context, labels "pernicious assimilation" in which small-scale food vendors are forced to operate from statecontrolled wet markets, and street vendors outside the market system are tightly policed. However, as Dai, Zhong, and Scott (in this issue) argue, the effectiveness of state control of street vending is undermined by personal ties and shared histories between state officials and vendors (many of whom are marginalized and landless farmers). Their notion of "compensatory governance" provides an interesting example of how state agents can seek to redress the deeper processes of dispossession and injustice that accompany urban transitions and city life. This suggests a line of inquiry worth pursuing in Africa; in other words, what happens when state agents and informal food vendors come from the same communities, face similar livelihood challenges, and may have familial, social, or other personal ties? In sum, by demonstrating how case study evidence can offer important insights into alternative forms of governance of informal economic activity in the food sectr, these papers mark an important break with the idea that state responses to informality are always and everywhere repressive in nature.

Another group of papers in this Special Issue take a different approach to the analysis of the resilience of informal food vending in African cities. These papers adopt the view that the informal sector is not the last refuge of the marginalized and dispossessed, but a site of considerable entrepreneurial agency, energy, and innovation. The first of these, by Godfrey Tawodzera (in this issue), focuses on the informal food sector in Cape Town, South Africa, a sector dominated by internal and international migrants to the city. Contesting the view that informal sector participation is an ephemeral activity with high rates of business failure, his study suggests that barriers to entry are extremely low and that enterprising individuals are able not only to survive but to build sustainable businesses, despite the fact that there are few formal sources of outside financing and competition is extremely fierce. Previous studies have highlighted the xenophobic violence and lack of state protection face by informal migrant traders in the city (Crush et al. 2015, 2017b; Steinberg 2015). While there is unassailable evidence of 
the destructive impact of popular and state xenophobia, only a minority of vendors see this as a significant challenge. Their major pre-occupation is with the intense competitiveness of the sector which raises the question of why the state does not open up more city spaces for legitimate trading.

The second paper, by Ines Raimundo and Cameron McCordic (in this issue), focuses on informal youth entrepreneurship in Maputo, Mozambique, and tackles the daunting challenge of youth unemployment in Africa. While most neoliberal orthodoxies suggest that the key to reducing youth unemployment is formal sector expansion and job creation, they adopt the alternate position that the informal sector is already providing entrepreneurial opportunities for youth recorded as "unemployed" in official statistics (Dolan and Rajak 2016; Langevang and Gough 2012). Basing their analysis, like Tawodzera, on extensive survey material collected by the Hungry Cities Partnership, they offer a picture of the informal food economy as a space of inclusion and potential upward mobility for youth. In doing so, they present research findings on why individual youth vendors in Maputo engage in the informal food economy, but also the challenges they face when engaging in these activities.

Taken together, the survey results in these articles suggest that vendors are motivated by a variety of factors ranging from the need for money, family support, and the inability to find a job, to the desire to run their own business and be their own boss. Complicating matters further, it is possible for an individual to be motivated by several interconnected push and pull factors that shape their participation in informal food economies, making it difficult to construct concrete, universal narratives of cause and effect. This plurality of motivations could support the position that informality is an opportunity for some and a necessity for others (Günther and Launov 2012; Williams and Gurtoo 2012; Williams and Youssef 2015). It must also, however, be viewed in relation to the reality that informal economies have deep internal hierarchies and class structures in which participants are segmented by income levels, poverty risk, and gender composition (Chen 2012, 9).

The paper by Ndeyapo Nickanor, Lawrence Kazembe, and Jonathan Crush (in this issue) examines whether the expansion of supermarkets in Windhoek, Namibia, has impacted negatively on the informal food sector, an issue that has pre-occupied debates about the supermarket revolution in Africa and elsewhere (Abrahams 2010; Crush and Frayne 2011; Gorton et al. 2011; Minten et al. 2010). Explanations for why informal food systems may survive, and even thrive, commonly refer to spatial differentiation in which supermarkets and the informal sector target different parts of the city (Berger and van Helvoirt 2018), or market segmentation in which supermarkets provide higher quality goods at higher prices to wealthier consumers, limiting direct competition (Schipmann and Qaim 2011). In Windhoek, neither spatial segmentation nor market differentiation fully explain the vibrancy and expansion of the informal food sector. Instead, the resilience of the informal food economy can be explained by "cohabitation," a process in which informal food vendors coexist with, and sometimes benefit from, supermarkets in two ways: first, by gaining business from customers and employees of supermarkets; and second, by using supermarkets as a source for produce and taking advantage of competition between supermarkets to acquire goods for resale at lower prices.

The contributions to this Special Issue, and the wealth of data they present, offer several pointers for further reflection. First, the papers do not aim to present a unified narrative of informal food economies in African and other cities in the Global South. 
Such a narrative would necessarily fail to capture the complex dynamics of informality in the cities under focus and overlook the importance of contextual specificity. Instead, they emphasize this complexity and the diverse perspectives that emerge from encounters with different aspects of informal economies across a wide variety of urban settings. The theoretical and empirical insights that emerge have much to offer to current debates about the origins of informality, the role of the informal food sector in the promotion of inclusive development, the relationship between informal vendors and the state, and interactions between informal and formal food systems. Just as importantly, they illustrate the impressive scope of what we still do not know about informal economies, the problems that remain to be solved, and the questions that demand further scrutiny.

Second, an emphasis on context and internal complexity demands that careful attention be paid to how empirical data is interpreted. While a standard set of questions can be posed to informal vendors across a diverse collection of cities, the answers provided can only be given their full meaning and significance in reference to the specific realities of informality in a given site under study. Quantitative work must therefore be combined with qualitative work that grounds data in local contexts and allows vendors' responses to illuminate deeper insights into the forms that informality can take. This may complicate efforts to draw generalizable conclusions and extrapolate "best practice" policy guidelines from detailed case study work but, at the same time, it further underscores the need for extensive empirical research in a wide variety of African and other Southern cities to approach a more comprehensive theorization of informal food sector activity.

Finally, recognizing the central role of the state in the origins of informal economic activity has profound policy implications. If the state does not merely act upon the informal economy, but is fundamental to its very existence, then governance is more than merely a set of policies, enforcement patterns, and targeted development plans; it is also a function of the core institutions, political processes, economic arrangements, and power dynamics that constitute the state. Minor policy adjustments are unlikely to alter the power dynamics that are at the heart of the relationship between the informal economy and the state, and therefore unlikely to succeed in the promotion of inclusive development. Informal economic governance that truly empowers the urban poor can only come with more systemic structural change. Given the power dynamics at play; however, the obstacles to change are clearly significant.

Acknowledgments The International Development Research Centre (IDRC), the Social Sciences and Humanities Research Council of Canada (SSHRC) and the Queen Elizabeth Advanced Scholars Program are thanked for their support of this Special Issue through the International Partnerships in Sustainable Societies (IPaSS) program.

\section{References}

Abrahams, C. (2010). Transforming the region: supermarkets and the local food economy. African Affairs, $109,115-134$.

Battersby, J., \& Watson, V. (Eds.). (2019). Urban food systems governance and poverty in African cities. London: Routledge.

Bénit-Gbaffou, C. (2016). Do street traders have a 'right to the city'? The politics of street trader organisations in inner city Johannesburg, post-operation clean sweep. Third World Quarterly, 37, 1102-1129. 
Berger, M., \& van Helvoirt, B. (2018). Ensuring food secure cities: retail modernization and policy implications in Nairobi, Kenya. Food Policy, 79, 12-22.

Chen, M. (2012). The informal economy: definitions, theories and policies (WIEGO working paper no. 1). Cambridge MA: WIEGO.

Crush, J., \& Battersby, J. (Eds.). (2016). Rapid urbanization, urban food deserts and food security in Africa. Dordrecht: Springer.

Crush, J., \& Frayne, B. (2011). Supermarket expansion and the informal food economy in southern African cities: implications for urban food security. Journal of Southern African Studies, 37, 781-807.

Crush, J., Chikanda, A., \& Skinner, C. (Eds.). (2015). Mean streets: migration, xenophobia and informality in South Africa. Ottawa: IDRC.

Crush, J., Skinner, C., \& Stulgaitis, M. (2017a). Benign neglect or active destruction? A critical analysis of refugee and informal sector policy and practice in South Africa. African Human Mobility Review, 3, 751782 .

Crush, J., Tawodzera, G., Chikanda, A., \& Tevera, D. (2017b). The owners of xenophobia: Zimbabwean informal enterprise and xenophobic violence in South Africa. African Human Mobility Review, 3, 879909.

de Soto, H. (1989). The other path: the invisible revolution in the Third World. New York: Harper \& Row.

Dolan, C., \& Rajak, D. (2016). Remaking Africa's informal economies: youth, entrepreneurship and the promise of inclusion at the bottom of the pyramid. Journal of Development Studies, 52, 514-529.

Dragsted-Mutengwa, B. (2018). Street traders and "good officers": crackdowns as a relational form of urban governance in Nairobi. Journal of Urban Research, 17-18.

Finn, B. (2018). Quietly chasing Kigali: young men and the intolerance of informality in Rwanda's capital city. Urban Forum, 29, 205-218.

Frayne, B., Crush, J., \& McCordic, C. (Eds.). (2018). Food and nutrition security in southern African cities. London: Routledge.

Gorton, M., Sauer, J., \& Supatpongkul, P. (2011). Wet markets, supermarkets and the "big middle" for food retailing in developing countries: evidence from Thailand. World Development, 39, 1624-1637.

Günther, I., \& Launov, A. (2012). Informal employment in developing countries: opportunity or last resort? Journal of Development Economics, 97, 88-98.

Hart, K. (1973). Informal income opportunities and urban employment in Ghana. Journal of Modern African Studies, 11, 61-89.

Holland, A. (2017). Forbearance as redistribution: the politics of informal welfare in Latin America. Cambridge: Cambridge University Press.

Kamete, A. (2013). Missing the point? Urban planning and the normalisation of 'pathological' spaces in southern Africa. Transactions of Institute of British Geographers, 38, 639-651.

Kamete, A. (2017). Governing enclaves of informality: unscrambling the logic of the camp in urban Zimbabwe. Geoforum, 81, 76-86.

Kamete, A. (2018). Pernicious assimilation: reframing the integration of the urban informal economy in Southern Africa. Urban Geography, 39, 167-189.

Kazembe, L., Nickanor, N. \& Crush, J. (2019). Informalized containment: food markets and the governance of the informal food sector in Windhoek, Namibia. Environment \& Urbanization (in press).

Langevang, T., \& Gough, K. (2012). Diverging pathways: young female employment and entrepreneurship in sub-Saharan Africa. Geographical Journal, 178, 242-252.

Mackie, P., Bromley, R., \& Brown, A. (2014). Informal traders and the battlegrounds of revanchism in Cusco, Peru. International Journal of Urban and Regional Research, 38, 1884-1903.

Meagher, K. (2010). Identity economics: social networks and the informal economy in Nigeria. Oxford: James Currey.

Minten, B., Reardon, T., \& Sutradhar, R. (2010). Food prices and modern retail: the case of Delhi. World Development, 38, 1775-1787.

Morange, M. (2015). Street trade, neoliberalisation and the control of space: Nairobi's Central Business District in the era of entrepreneurial urbanism. Journal of Eastern African Studies, 9, 247-269.

Moyo, I. (2018). Resistance and resilience by informal traders in Bulawayo, Zimbabwe: beyond weapons of the weak. Urban Forum, 29, 299-313.

Musoni, F. (2010). Operation Murambatsvina and the politics of street vendors in Zimbabwe. Journal of Southern African Studies, 36, 301-317.

Poku, N., \& Whitman, J. (Eds.). (2017). Neoliberalism in Africa. New York: Routledge.

Portes, A., Castells, M., \& Benton, L. (1989). The informal economy: studies in advanced and less developed countries. Baltimore: Johns Hopkins University Press.

Resnick, D. (forthcoming). The politics of crackdowns on Africa's informal vendors. Comparative Politics. 
Riley, L. (2014). Operation Dongosolo and the geographies of urban poverty in Malawi. Journal of Southern African Studies, 40, 443-458.

Roever, S., \& Skinner, C. (2016). Street vendors and cities. Environment \& Urbanization, 28, 359-374.

Schipmann, C., \& Qaim, M. (2011). Modern food retailers and traditional markets in developing countries: comparing quality, prices, and competition policy in Thailand. Applied Economic Perspectives and Policy, 33, 345-362.

Skinner, C. (2019). Contributing and yet excluded? Informal food retail in African cities. In J. Battersby \& V. Watson (Eds.), Urban food systems governance and poverty in African cities (pp. 104-115). London: Routledge.

Skinner, C., \& G. Haysom (2016). The informal sector's role in food security: a missing link in policy debates? (discussion paper no. 6). Cape Town and Waterloo: Hungry Cities Partnership.

Steel, W., Ujoranyi, T., \& Owusu, G. (2014). Why evictions do not deter street traders: case study in Accra, Ghana. Ghana Social Science Journal, 11, 52-76.

Steinberg, J. (2015). A man of good hope. New York: Vintage Books.

Tonda, N., \& Kepe, T. (2016). Spaces of contention: tension around street vendors' struggle for livelihoods and spatial justice in Lilongwe, Malawi. Urban Forum, 27, 297-309.

Williams, C., \& Gurtoo, A. (2012). Evaluating competing theories of street entrepreneurship: some lessons from a study of street vendors in Bangalore, India. International Entrepreneurship and Management Journal, 8, 381-409.

Williams, C., \& Youssef, Y. (2015). Theorising entrepreneurship in the informal sector in urban Brazil: a product of exit or exclusion? Journal of Entrepreneurship, 24, 148-168.

Young, G. (2017). From protection to repression: the politics of street vending in Kampala. Journal of Eastern African Studies, 11, 714-733.

Young, G. (2018). De-democratisation and the rights of street vendors in Kampala, Uganda. International Journal of Human Rights, 22, 1007-1029.

Young, G., \& Crush, J. (2019). Governing the informal food sector in cities of the Global South (discussion paper no. 30). Cape Town and Waterloo: Hungry Cities Partnership.

Publisher's Note Springer Nature remains neutral with regard to jurisdictional claims in published maps and institutional affiliations. 